\title{
A Preliminary Economic Evaluation of Rare Earth Element and Yttrium (REY) in Indonesian Coal: Progress and Future Prospect
}

\author{
Aulia Agus Patria ${ }^{1 *}$, Ferian Anggara ${ }^{2,3}$ \\ ${ }^{1}$ Undergraduate Student Program, Department of Geological Engineering, Faculty of Engineering, \\ Universitas Gadjah Mada, Yogyakarta, Indonesia \\ ${ }^{2}$ Department of Geological Engineering, Faculty of Engineering, \\ Universitas Gadjah Mada, Yogyakarta, Indonesia \\ ${ }^{3}$ Unconventional Geo-resources Research Group, Faculty of Engineering, \\ Universitas Gadjah Mada, Yogyakarta, Indonesia \\ *Corresponding author: aulia.agus.patria@mail.ugm.ac.id
}

Article received: 4 December 2020, revised: 15 March 2021, accepted: 15 July 2021

DOI: $10.51835 /$ ijeg.2021.1.1.339

\begin{abstract}
Coal deposits have fascinated much attention in recent years due to its by-product waste as promising alternative sources for rare earth metals. Rare earth metals concentration in many coals and coal ashes are known have equal to or higher than those found in conventional ore. Indonesia is one of the most extensive coal-bearing sedimentary basins in SE Asia with unique tectonic and geological control that might be significance as prospective country of rare metals recovery from coal. This study shows recent progress from several Indonesian coal-bearing sedimentary basins: Ombilin, South Sumatra and Pasir basin. Surprisingly, the REY concentration in Ombilin, South Sumatera and Pasir basin has higher than the average world-coal with 126.15 ppm, 203.72 and $285.53 \mathrm{ppm}$, respectively. Based on the relationship market demand and supply of individual REY in recent years proposed by Seredin and Dai (2012), all of coal samples were clustered into Promising (II) type with base of critical outlook is 0.7 and cut-off grade is $1000 \mathrm{ppm}$ in coal ashes. It comprises the various REY distribution types and can be regarded as promising REY raw metrials for economic development. REY-enrichment processes in Indonesian coal are different due its tectonic and geological processes that control the basin formation, both of pre-, syn- and post-forming. Genetically, major REY-enrichment processes in Indonesian coal are controlled by tuffaceous; infiltrational; and terrigenous process. Tuffaceous process is related to volcanism that produce tonstein layer during coal peatification, this type is determined in South Sumatera and Pasir basin. Terrigenous process is controlled by provenance sediment-source during coal-bearing formation is formed; basaltic-igneous basement is major controlled REY-enrichment in Ombilin and Pasir basin. Injections of marine water during coal peatification also known that lead REY-enrichment, this type called infiltrational type and its presence in all three basins. Recent study about REY-rich in Indonesian coal shows significance prospect for future rare earth metals recovery. Further study is needed in unexplored coal-bearing sedimentary basin such as Tarakan, Asem-asem, Barito, Ketungau, Melawi, Salawati and Bintuni basin.
\end{abstract}

Keywords: Coal, Indonesia, rare earth element and yttrium (REY)

\section{INTRODUCTION}

The used of Rare Earth Elements and Yttrium (REY) has grown due to their wide spread applications as metal catalyst, battery and various high-technology (Pecht et al., 2012). Under specific geological conditions REY can be significantly enriched in coals and coal ashes (Dai and Finkelman, 2008; Dai et al., 2012; Seredin and Dai, 2012).

Indonesia is known as the largest and most extensive coal deposits in South-East Asia, specifically in Sumatra and Kalimantan Island (Friederich et al., 2016). Several recent study by Anggara et al. (2018), showed that 
Indonesian coal have significant REY content due to their geological setting and processes.

In this paper we report the preliminary economic evaluation of Rare Earth Elements and Yttrium (REY) in Indonesian coal. The results have provided new data, evidence and further information for REY recovery from coal deposit in Indonesia.

\section{METHODOLOGY}

This research uses literature review from several previous research Anggara (2018; 2019), Fadhilah (2019), Patria (2020) from three different basin, South Sumatera, Pasir and Ombilin basin, respectively. The data shown in this paper was representative data to represent each basin. Representative data defined as the highest REY content in each basin. All of samples were consistently done by ICP-MS method to determine REY content, performed by ALS Canada Ltd. (Vancouver, Canada). All of data then compiled and proceed into new compilation data to evaluate the economic evaluation using equation and diagram given by Dai and Finkelman (2018).

\section{RESULTS AND DISCUSSION}

Rare Earth Element and Yttrium (REY) content in three known basin are higher than the average content those found in China, US, and world-hard coal (Dai et al., 2016). The REY content of concentration in Ombilin, South Sumatera and Pasir basin has higher than the average world-coal with $126.15 \mathrm{ppm}$, 203.72 and $285.53 \mathrm{ppm}$, respectively.

Economic evaluation of REY in coal can be done by several parameters proposed by Dai and Finkelman (2018): (1) reviewed by the cut-off grade of $\mathrm{REO}_{\text {ash }}(\geq 1000 \mathrm{ppm})$ and their critical outlook $\left(\mathrm{C}_{\text {outl }}=0.7\right)$; (2) using the calculation of Percentage REY def-rel (Critical REY/Total REY) and critical outlook $\left(\mathrm{C}_{\text {outl }}=0.7\right)$.

Based on calculation all of representative coal in three different basins are classified into Promising Area (II) with value of $\mathrm{C}_{\text {out }}$ $(0.7 \leq$ "X" $\leq 2.4), \mathrm{REO}_{\text {ash }}(\geq 1000 \mathrm{ppm})$ and $\mathrm{REY}_{\text {def-rel }}(30 \% \leq$ "X" $\leq 51 \%)$, all of data shown in Figure 1 and 2.

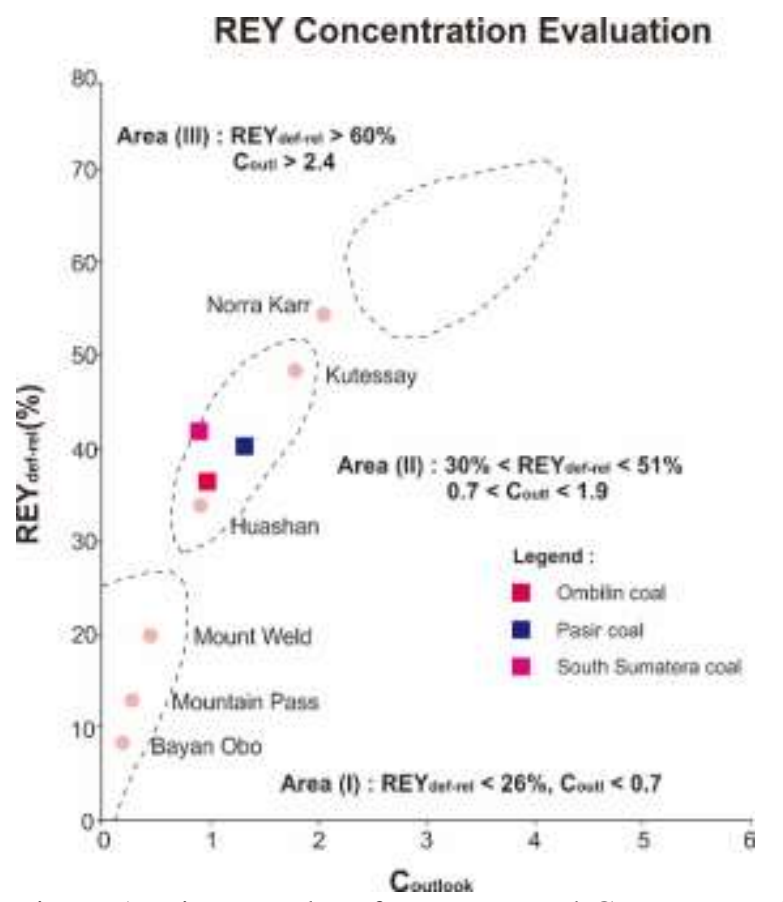

Figure 1. Diagram plot of $\mathrm{REY}_{\text {def-rel }}$ and $\mathrm{C}_{\text {outl }}$ proposed by Dai and Finkelman (2018), all of three coal samples are clustered into Area (II).

Based on data above, all of the coal samples were clustered into Promising Area (II). This cluster can be regarded as promising REY as raw materials for economic development, this suggestion was also supported by the fact that these cluster includes currently mined of Huposhan and Kutessay REY deposit. 


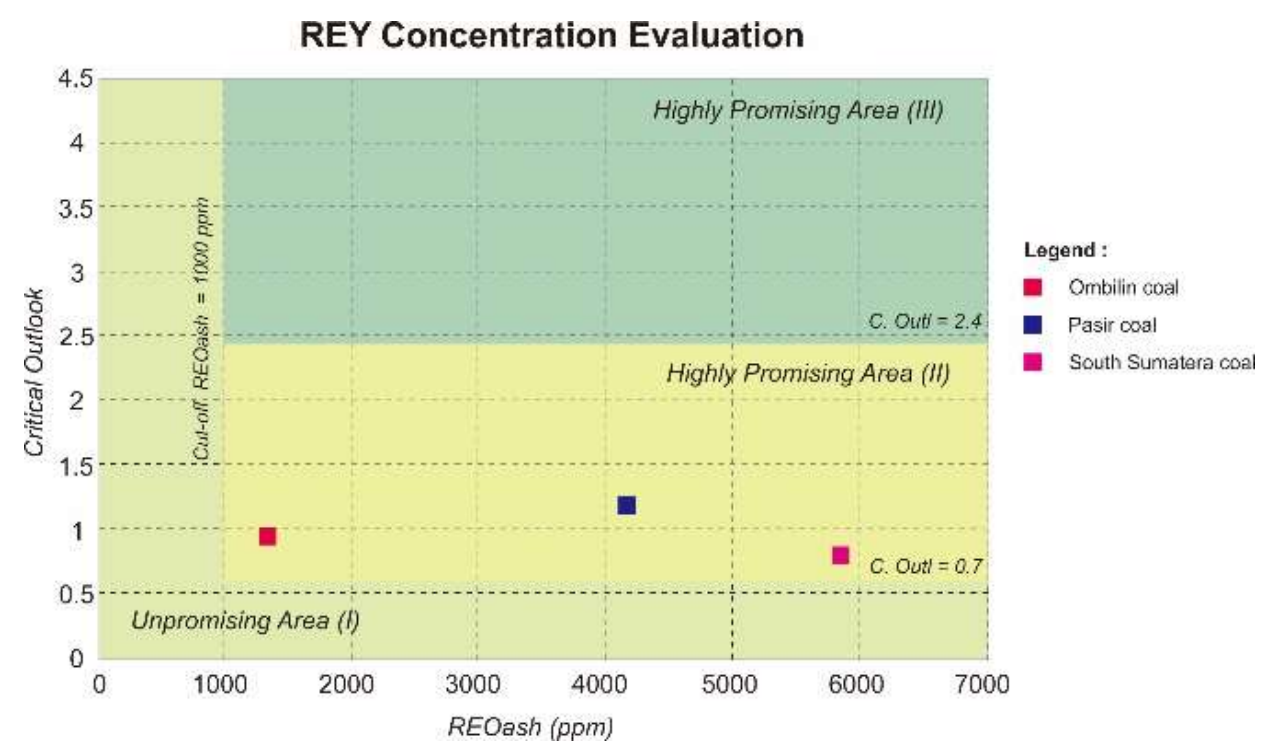

Figure 2. Diagram plot of $\mathrm{REO}_{\text {ash }}$ and $\mathrm{C}_{\text {outl }}$ proposed by Dai and Finkelman (2018), all of three coal samples are clustered into Highly Promising Area (II).

Genetically, the major REY-enrichment processes in Indonesian coal are controlled by tuffaceous; infiltrational; and terrigenous process. Tuffaceous process is related to volcanism that produce tonstein layer during coal peatification, this type is determined in South Sumatera and Pasir basin. Terrigenous process is controlled by provenance sediment-source during coal-bearing formation; basaltic-igneous basement is major controlled REY-enrichment in Ombilin and Pasir basin. Injections of marine water during coal peatification also known that lead REYenrichment, this type called infiltrational type and its presence in all three basins.

Recent study about REY-rich in Indonesian coal shows significance prospect for future rare earth metals recovery optimism. Further study is needed in unexplored coal-bearing sedimentary basin such as Tarakan, Asem-asem, Barito, Ketungau, Melawi, Salawati and Bintuni basin.

\section{CONCLUSION}

Indonesian coal from three known basin (Ombilin, South Sumatra, Pasir) has prospective unconventional deposit for rare earth metals. An economic evaluation suggests the Indonesian coal clustered into Promising Area (II), which means it possible as raw materials for economic deposit. Indonesia as large country with an extensive coal deposits may lead as global contributor for rare earth metals recovery from unconventional resources. Further study is needed for unknown coal-bearing sedimentary basin in Indonesia.

\section{REFERENCES}

Anggara, F., Amijaya, D. H., Harijoko, A., Tambaria, T. N., Sahri, A. A., and Asa, Z. A., (2018) "Rare earth element and yttrium content of coal in the Banko coalfield, South Sumatra Basin, Indonesia: Contributions from tonstein layers", International Journal of Coal Geology, 196, pp. 159-172.

Anggara, F., Cikasimi, M., Rahmat, B., Wibisono, S. A., Susilawati, and R., (2019) "Karakteristik dan genesa pengayaan unsur-unsur tanah jarang pada batubara lapangan Muara Tiga Besar Utara, Tanjung Enim, Cekungan Sumatera Selatan," Buletin Sumber Daya Geologi, 14(3), pp. 198212. 
Dai, S., Graham, I. T., and Ward, C. R., (2016) "A review of anomalous rare earth elements and yttrium in coal," International Journal of Coal Geology, 159, pp. 82-95.

Dai, S., and Finkelman, R. B., (2018) "Coal as a promising source of critical elements: Progress and future prospects", International Journal of Coal Geology, 186, pp. 155 - 164.

Fadhilah, A. A., (2019) Pengayaan Rare Earth Elements and Yttrium pada batubara eosen lapangan batubara Senakin, Kalimantan bagian tenggara, Indonesia, Thesis (Bachelor), Universitas Gadjah Mada, Yogyakarta, Indonesia.

Friederich, M. C., Moore, T.A., and Flores, R.M., (2016) "A regional review and new insights into SE Asian Cenozoic coal-bearing sediments: Why does Indonesia have such extensive coal deposits", International Journal of Coal Geology, 166 , pp. 2-35.
Patria, A. A., (2020) Potensi pengayaan rare earth element and yttrium (REY) pada batubara Formasi Sawahlunto, Cekungan Ombilin, Sumatra Barat, Thesis (Bachelor), Universitas Gadjah Mada, Yogyakarta, Indonesia.

Pecht, M. G., Kaczmarek, R. E., Song, X., Hazelwood, D. A., Kavetsky, R. A., and Anand, D. K., (2012) Rare Earth Materials: Insights and Concerns. CALCE EPSC Press, College Park, MD, USA, pp. 194.

Seredin, V. V. and Finkelman, R. B., (2008) "Metalliferous coals: A review of the main genetic and geochemical types", International Journal of Coal Geology. Elsevier B.V., 76(4), pp. 253-289. doi: 10.1016/j.coal.2008.07.016.

Seredin, V. V. and Dai, S., (2012) "Coal deposits as potential alternative sources for lanthanides and yttrium", International Journal of Coal Geology, 94, pp. 67-93, doi:10.1016/j.coal.2011.11.001. 